\title{
Burrowing Owl Monitoring Report for Calendar Year 2012
}

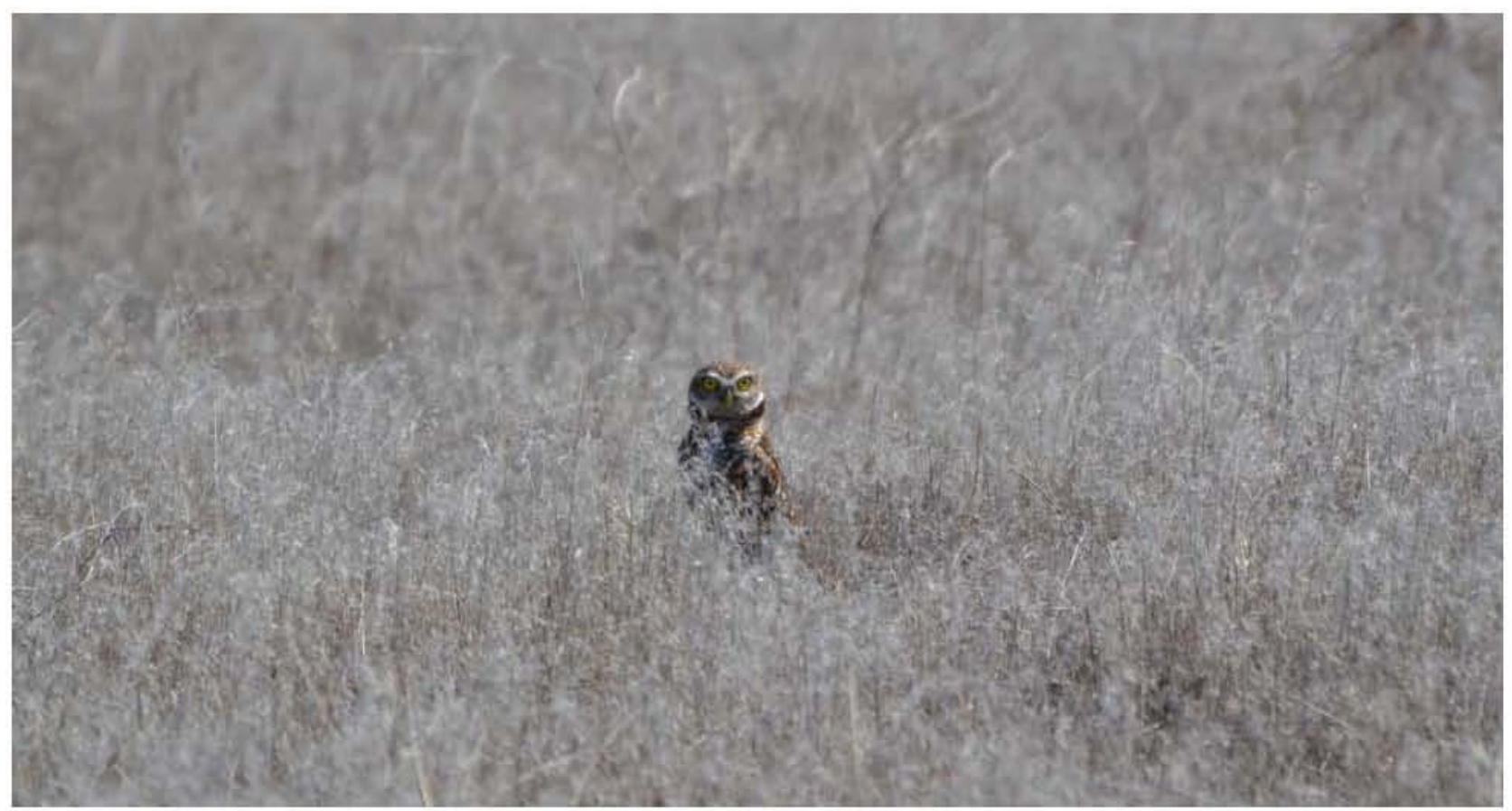

Prepared for the U.S. Department of Energy

Assistant Secretary for Environmental Management

Contractor for the U.S. Department of Energy

under Contract DE-AC06-09RL14728

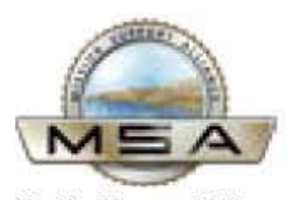

P.O. Box 650

Richland, Washington 99352 
HNF-54294

Revision 0

TRADEMARK DISCLAIMER

Reference herein to any specific commercial product, process, or service by trade name, trademark, manufacturer, or otherwise, does not necessarily constitute or imply its endorsement, recommendation, or favoring by the United States Government or any agency thereof or its contractors or subcontractors.

This report has been reproduced from the best available copy.

Printed in the United States of America

The cover photo is courtesy of Justin Wilde 


\section{Burrowing Owl Monitoring Report for Calendar Year 2012}

J. Wilde, C. Lindsey, and J. Nugent

mission Support Alliance

Date Publisted

March 2013

Prepared for the U.S. Department of Energy

Assistant Secretary for Environmental Management

Contractor tor the U.S. Department of Energy

under Contract DE-AC06-09RL14728

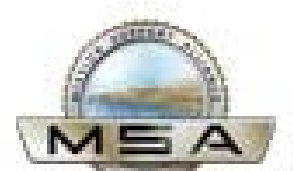

P.0. Box 650

Richland, Was hington 99352 

HNF-54294

Revision 0

\section{Contents}

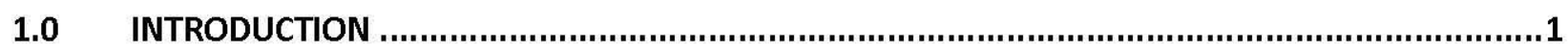

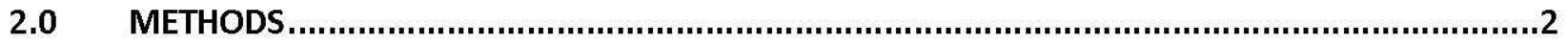

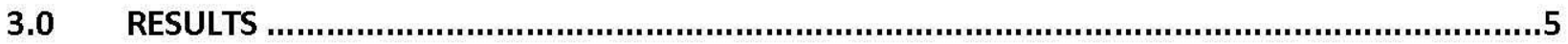

DISCUSSION

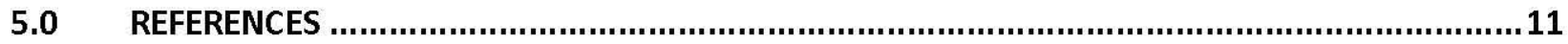

\section{Figures}

Figure 1. Burrowing Owl using Fence Post near Roadway as Perch on the Hanford Site ............................. 2

Figure 2. Historical Burrow Locations known prior to 2012 on DOE Managed Lands.................................... 3

Figure 3. Field Team Members Document the Status of an Artificial Burrow on the Hanford Site ................. 4

Figure 4. Active Clay Pipe Burrow with many Survey Identifiers such as Feathers, Castings, and

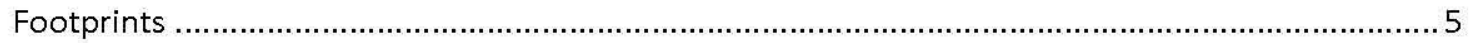

Figure 5. Previously undocumented burrow locations obtained during 2012 surveys................................ 6

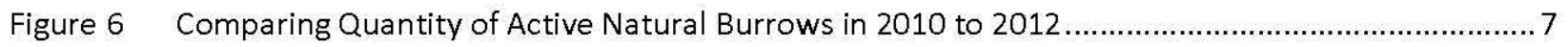

Figure 7. Active Burrows Documented during 2012 Surveys ........................................................................ 8

Figure 8. Current known extent of Burrowing owl burrow locations on DOE Managed Lands ................... 10 



\subsection{Introduction}

The burrowing owl (Athene cunicularia) is classified as a Washington Department of Fish and Wildlife Candidate Species. Burrowing owls are also protected under the Migratory Bird Treaty Act (MBTA). Conway et al. (2006) suggested that the reason for the population decline in Washington may be the reduction in numbers of ground squirrels, yellow-bellied marmots, and badgers, but loss of habitat to the intensification of agriculture and development has also affected the species. Most individuals that nest on the Hanford Site migrate and spend winter in areas much further south. Because the owls migrate to and nest on the Hanford Site and the Hanford Reach National Monument, the burrowing owl populations and the locations of burrows are of concern locally to the U. S. Department of Energy (DOE) and the U.S. Fish and Wildlife Service (USFWS).

Burrowing owls hunt all day and all night with peak activity levels in the morning and evening. The owls capture insects such as grasshoppers and beetles during the day and small mammals such as mice at night (Haug 1993). Burrowing owls collect dung of other animals and surround a burrow with the excrement in hopes of luring insects such as beetles that the owls capture and eat (Levy 2004).

Typical burrowing owl habitat includes deserts, grasslands, prairies, other natural areas, agricultural lands and man-altered environments. Although burrowing owls are thought to prefer habitat that has not been modified by man, they are found in proximity to humans at golf courses, airports and in suburban areas (Coulombe 1971) (Figure 1). Unlike other owl species, the burrowing owl nests underground rather than in trees or other above-ground structures. The owls typically use abandoned burrows created by badgers, coyotes, and ground squirrels. It is believed burrowing owls are capable of digging their own burrows, but often prefer those left by other animals (Haug 1993). Burrowing owls prefer open, short grass habitat with suitable perches near the burrow to survey for both predators and prey.

Monitoring burrowing owl populations contributes to the management and protection of the species, the maintenance of site-wide biological diversity and resource management, and assists with proper impact assessment of Hanford Site projects. Many Hanford Site projects include impacts to the ground surface with activities such as; grubbing, excavating, burning, off-road driving, compacting, and leveling. Without good documentation of current owl burrow locations it can be difficult to provide guidance on their protection. Continued monitoring and protection of this state candidate species will help to assure the continued presence of burrowing owls on the Hanford Site. 


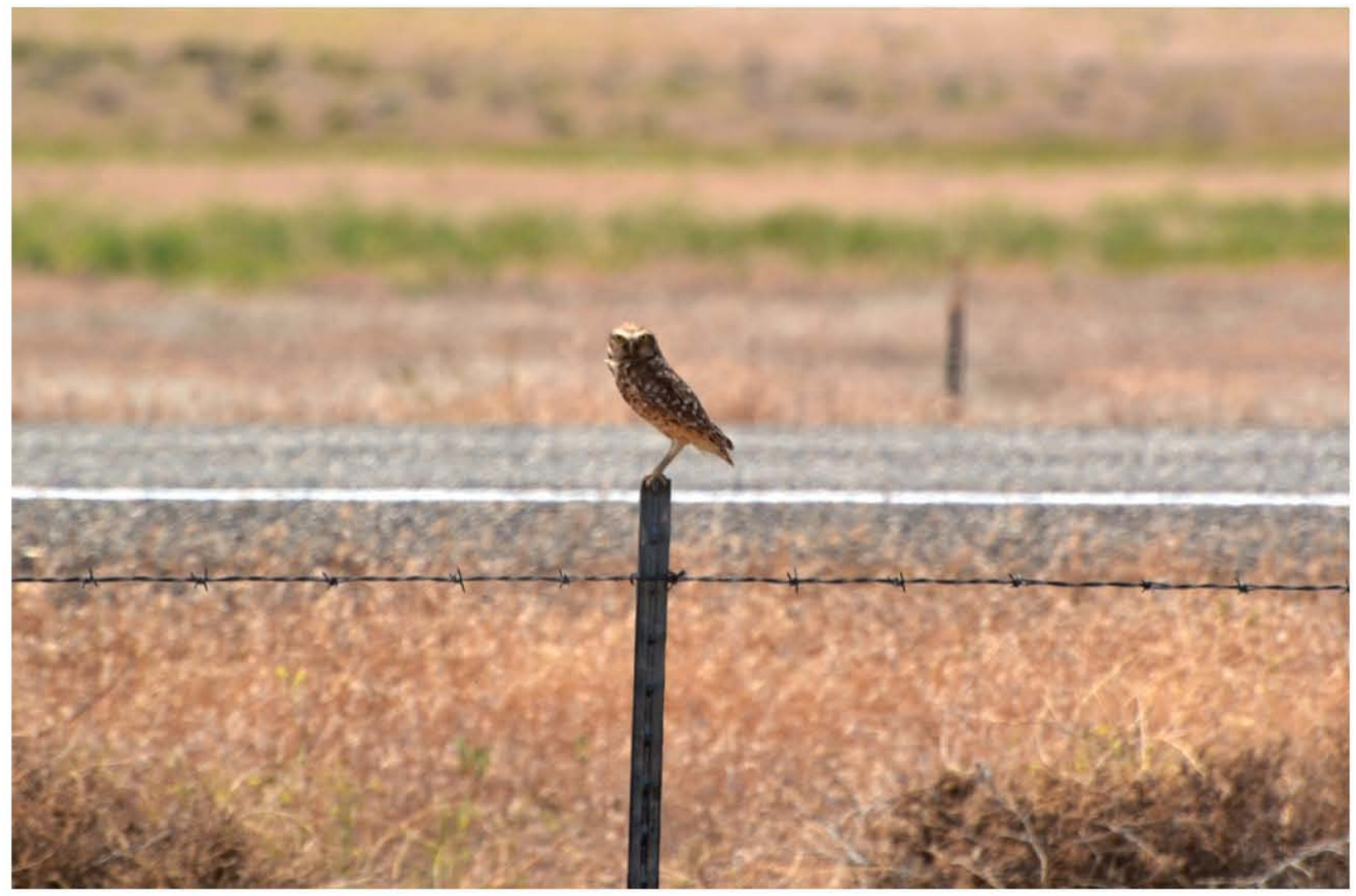

Figure 1. Burrowing Owl using Fence Post near Roadway as Perch on the Hanford Site

\subsection{Methods}

Historical burrow locations were visited to determine the current status of burrowing owls on the Hanford Site. Burrows were visited during the common residency window for burrowing owls (February-September). To avoid interfering with breeding of the owl populations, the surveys were performed in the month of May. At this point in the season most of the owlets have hatched, but have not matured enough to resemble adults. Later in the season the young may temporarily occupy nearby burrows, which could result in an over-estimation of burrow occupation.

The last census of burrowing owl nesting sites on the Hanford Site occurred in 2010. In 2012, all 110 known burrows (active and inactive) on Department of Energy (DOE) managed lands (Figure 2) were visited and the current status of each was determined. Field team members walked to each burrow location using Global Positioning System (GPS) coordinates (Figure 3). While approaching the burrow, field members visually scanned the area, looking for signs of occupation. An owl that directly left the burrow being visited was watched during the short flight and the location of its landing was noted. The area where the flushed owl landed was examined to determine if additional burrows were in the vicinity of the one tracked by the GPS unit. Field team members determined if a burrow was active by looking for owls in the burrow, or the presence of castings, feces, feathers and footprints at the opening of the burrow (Figure 4). The burrow was labeled as a nest if the burrow was a high use centralized burrow or if owl young were seen at the location. Additional classes of burrow activity included inactive, unusable, satellite, and potential for future use. Brief scans of the surrounding area for additional burrows were 
HNF-54294

Revision 0

made at each location. All newly discovered burrows were documented with the GPS system and added to the Hanford Site burrow database.

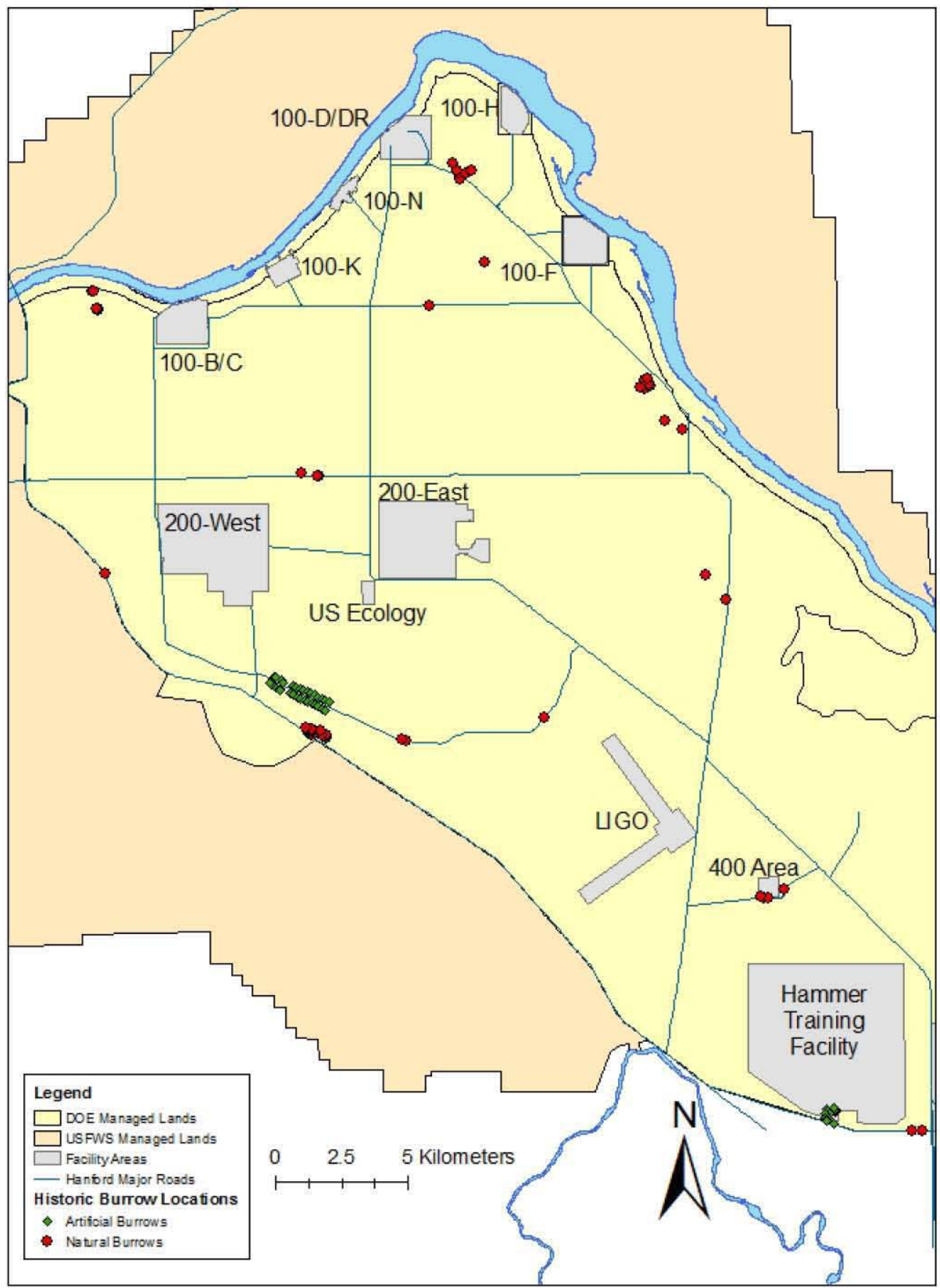

Figure 2. Historical Burrow Locations known prior to 2012 on DOE Managed Lands 


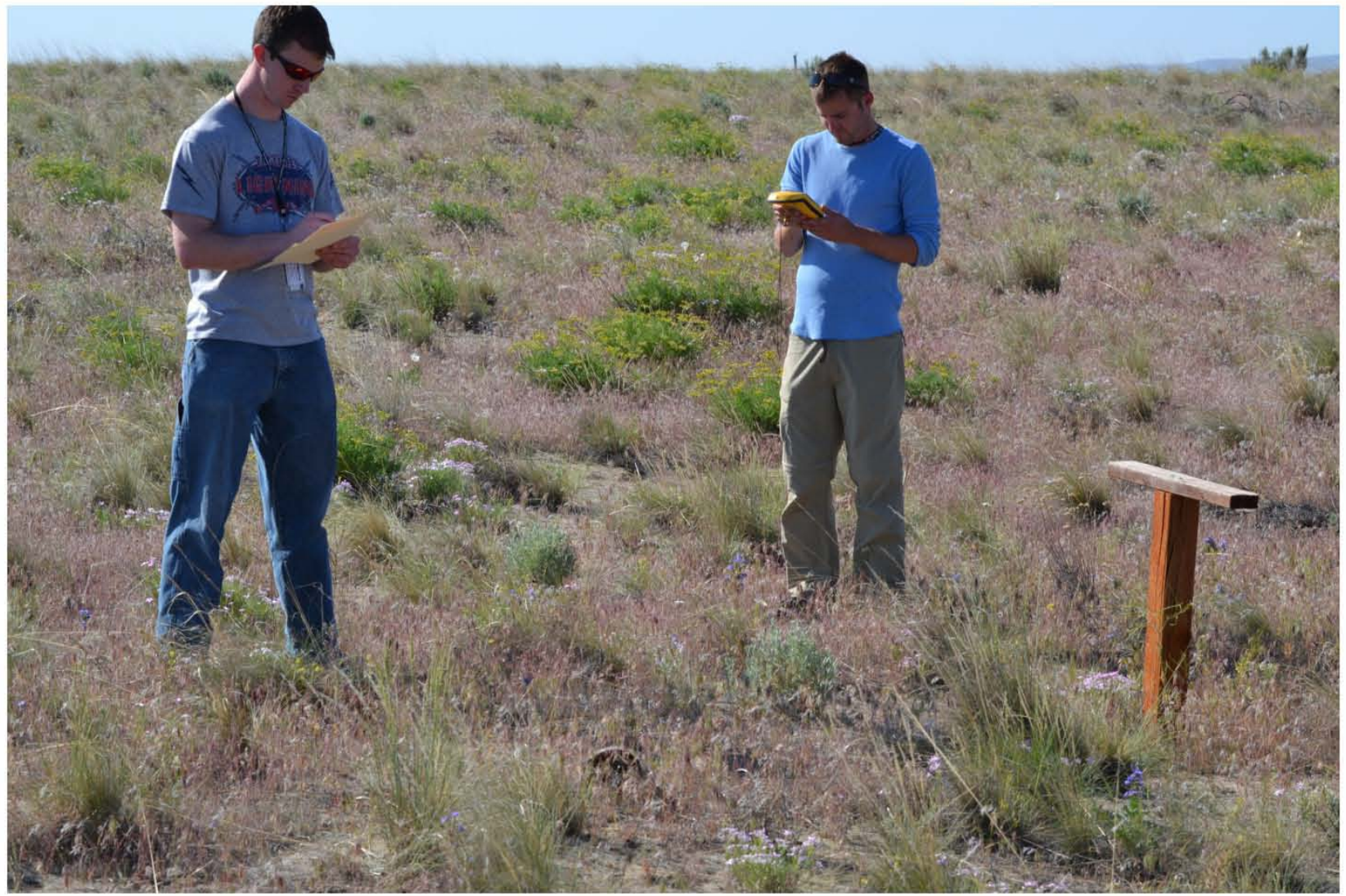

Figure 3. Field Team Members Document the Status of an Artificial Burrow on the Hanford Site

In addition to all of the known natural burrows around the Hanford Site, field team members reviewed artificial burrows that various site contractors have installed as part of habitat mitigation actions. The same status categories used for the natural burrows were used for the artificial burrows with the addition of a category labeled as maintenance required. Maintenance required was assigned to artificial burrows in which the burrow opening was obstructed by soil or vegetation, preventing the use of the burrow. 


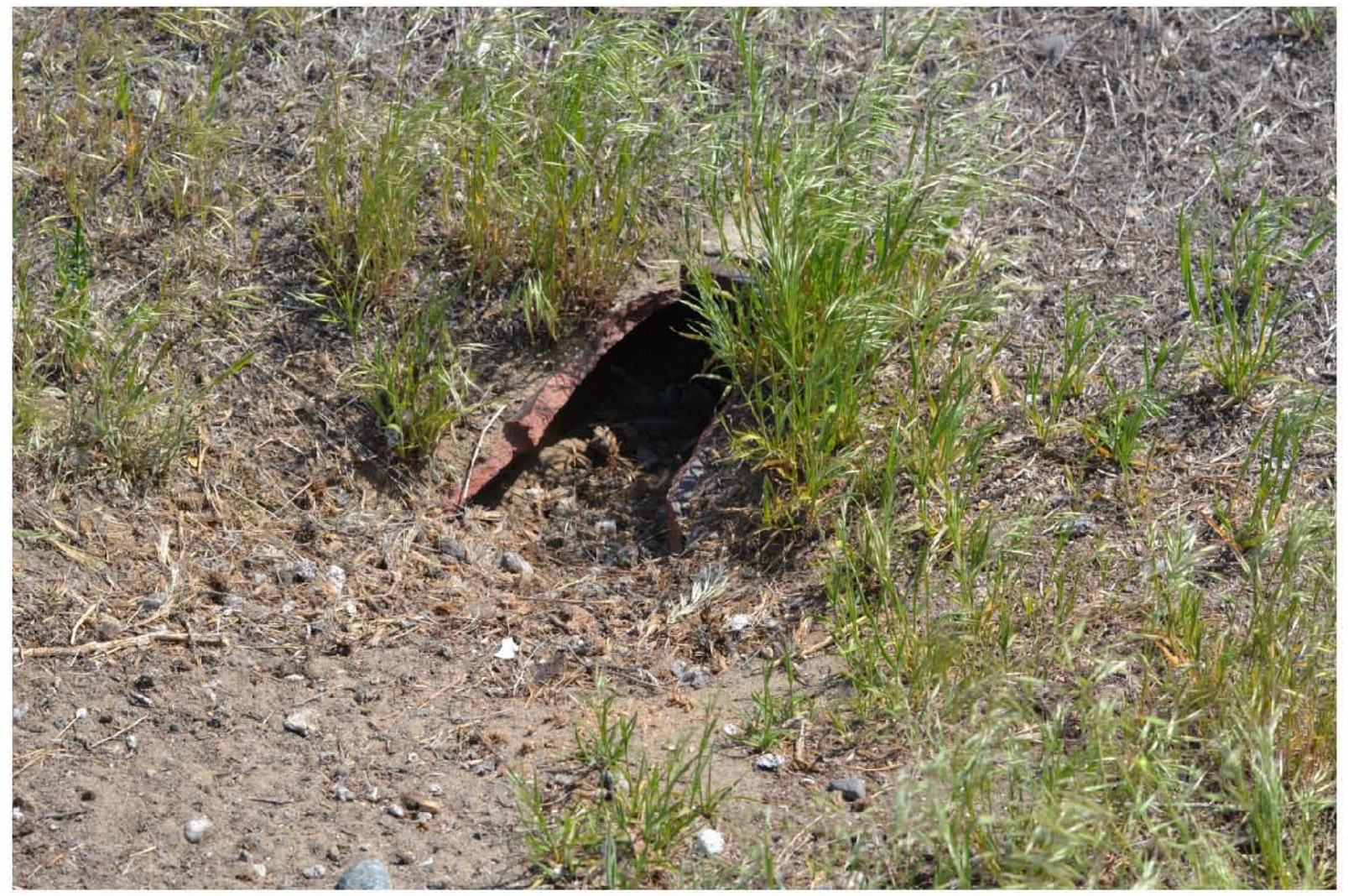

Figure 4. Active Clay Pipe Burrow with many Survey Identifiers such as Feathers, Castings, and Footprints

\subsection{Results}

Field staff evaluated 110 historical burrows over seven surveys during May, 2012. Field staff located all the historical burrows and documented the current status of each (See Appendix). For the purpose of this report the term "natural burrow" is defined as a location at which the original use or intent of space was not burrowing owl habitat. Thus a "natural burrow" could be a hole excavated by a fossorial mammal or a man-made object such as a pipe or culvert that was discovered and occupied by owls. "Artificial burrows" are structures that were installed specifically for the purpose of attracting burrowing owls.

As of 2010, the historical database consisted of 58 natural burrows; the status of each of these was determined in May, 2012. Artificial burrows were not reviewed in 2010 so no comparisons can be made. In 2010, 22 natural burrows were designated as active. Of those 22 sites, 12 remained active in 2012, additionally, 4 natural burrows that were classed as inactive or unknown in 2010 became active in 2012. During the 2012 monitoring effort an additional 13 natural burrowing owl burrows were located (Figure 5), 7 of which were designated as active status bringing the total to 23 active natural burrows on the Hanford Site. 
HNF-54294

Revision 0

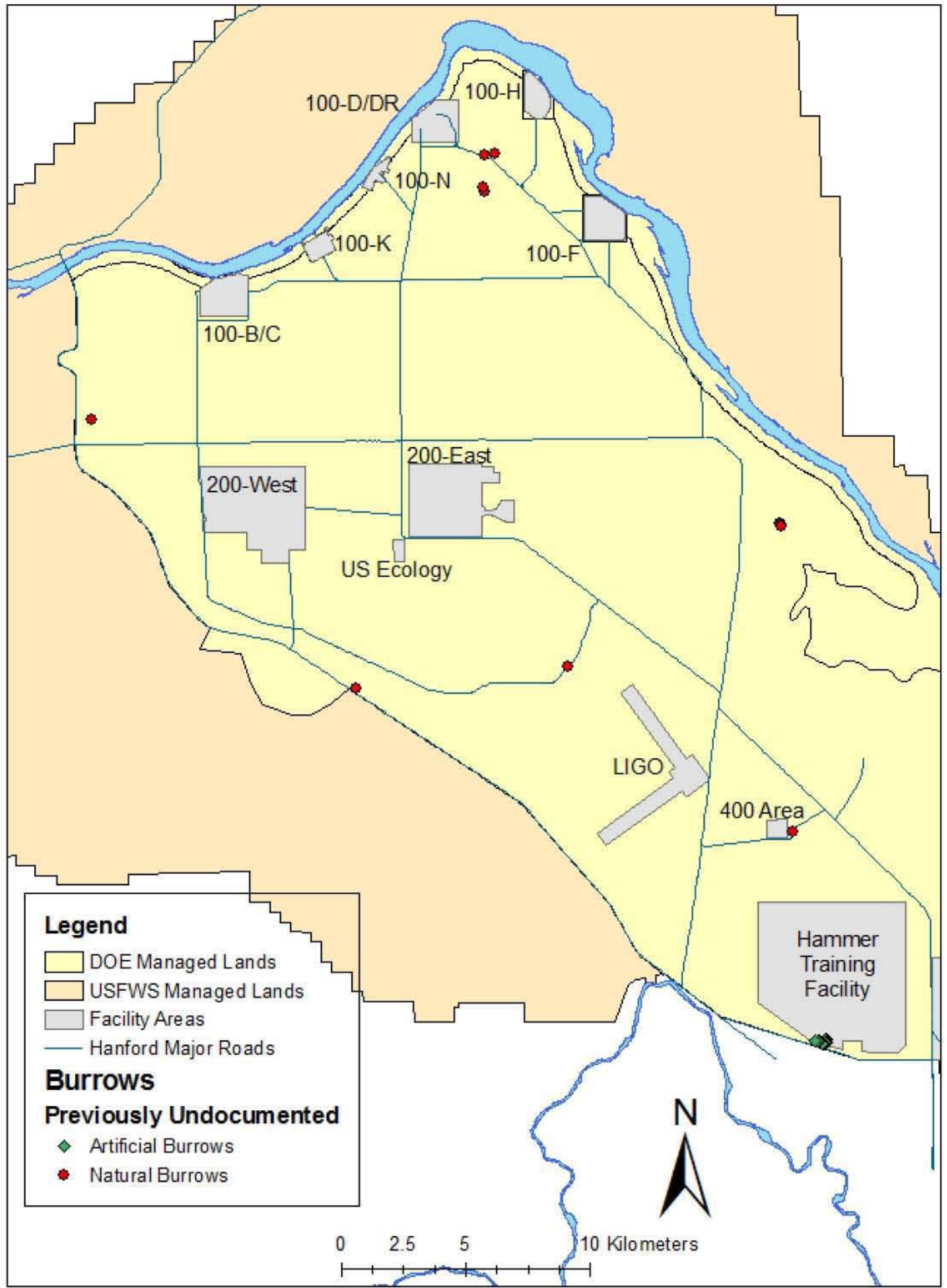

Figure 5. Previously undocumented burrow locations obtained during 2012 surveys 
The 2012 monitoring effort also documented the current status of the 52 artificial burrows listed in the database. Field team members located an additional 13 artificial burrows which had not been included in the database bringing the total number of artificial burrows on the Hanford Site to 65 . Monitoring was not performed in 2010 on the artificial burrows but it was found that 16 of the 65 artificial burrows were active in 2012. All of the active artificial burrows were either within the Emergency Vehicle Operations Course (EVOC) near HAMMER or in the area west of the EVOC. A total of 35 artificial burrows have been installed in this area. The 2012 monitoring effort revealed that upkeep of the artificial burrows has lapsed and of the 65 burrows, 29 required maintenance or were unusable in the current condition.

The total number of active natural burrows in 2012 (23) was very similar to the number of active natural burrows counted during 2010 (22). However, the 2012 total consisted of more man-made type structures such as pipes, culverts and other structures and fewer natural mammal digs or other soil based burrows compared to 2010 (Figure 6). The 23 active natural burrows and the 16 active artificial burrows give the Hanford site a total of 39 active burrows during the 2012 season (Figure 7).

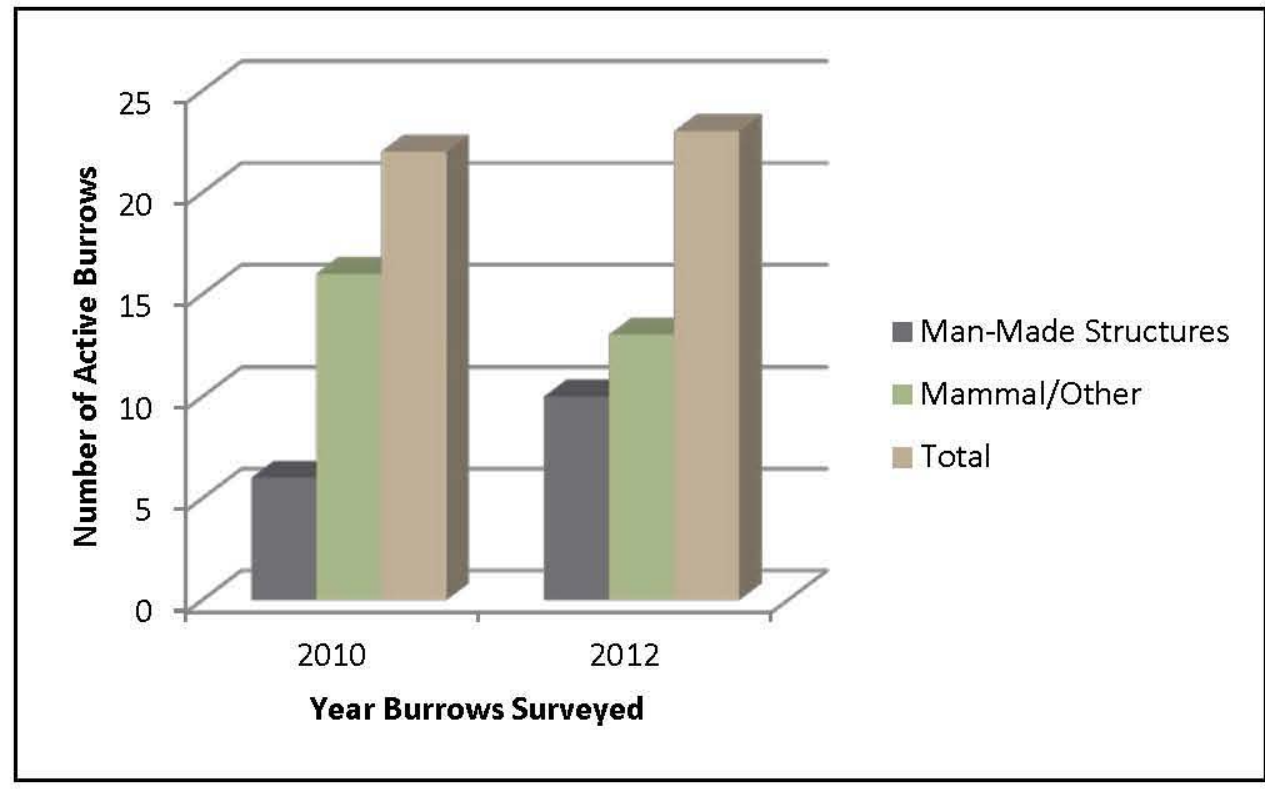

Figure 6 Comparing Quantity of Active Natural Burrows in 2010 to 2012 
HNF-54294

Revision 0

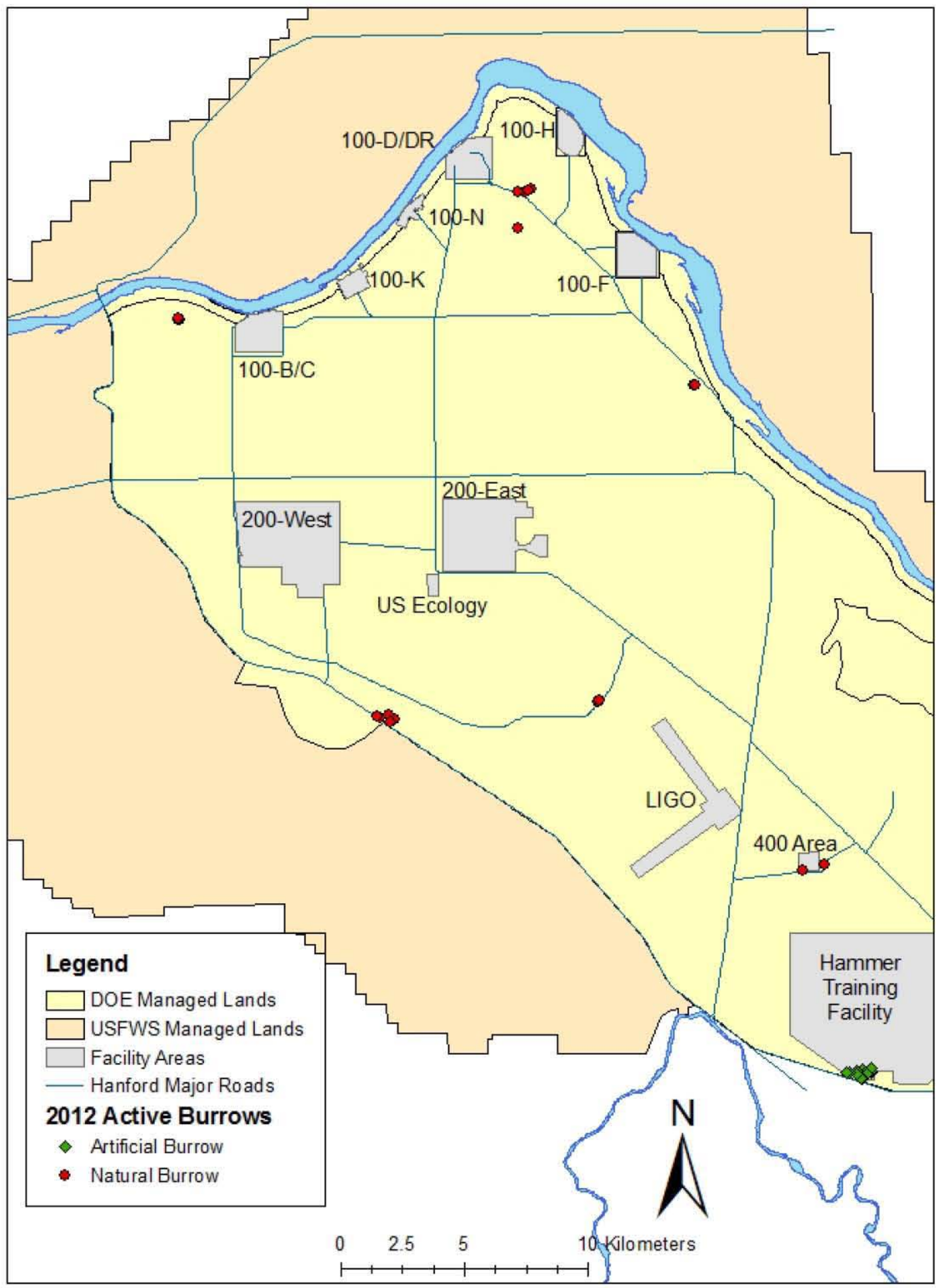

Figure 7. Active Burrows Documented during 2012 Survey 


\subsection{Discussion}

The monitoring during 2012 focused on documenting the status of known burrows. Newly identified burrows were documented while examining historical locations, during ecological resource reviews, or discovered during other monitoring efforts. The timing of the monitoring effort allowed staff to perform the surveys without disrupting any breeding or hatching, while also allowing for easy discernment of adults from juveniles, which helped in determining burrow-use type.

The total number of active burrows in 2012 was very similar to the number in 2010, but a trend of an increase in the proportion of natural burrows occurring in man-made structures, as opposed to burrows of fossorial mammal holes, was observed. It is believed that most natural, soil-based burrows have on average a life span of 2.74 years (Bradbury 2010), which may explain why the number of active soil based burrows documented during 2010 went down by 2012. In order to avoid misrepresenting a reduction of burrowing owls by only documenting the status of previously identified burrows, future surveys will also focus on locating new burrows by performing surveys in larger areas around known nest sites. Continued work will help to establish long-term trends of burrowing owl numbers on the Hanford Site. Because these numbers are not available historically, it is not possible to determine how current levels compare to historical levels. Threats to burrowing owl populations include habitat loss and reduced populations of Townsend's ground squirrels (Urocitellus townsendii) and badgers (Taxidea taxus), that provide needed burrows. Monitoring of ground squirrel populations and protection of habitat areas surrounding burrowing owl burrows will assist with burrowing owl management.

Efforts in 2013 will limit focus on monitoring of all known burrow locations (Figure 8) to the 39 active burrows, the artificial burrows, and natural burrows that were listed as having a continued potential for use. The artificial burrows on the DOE managed lands will receive maintenance prior to the spring and potential owl use. A portion of the burrowing owl population in the area over winters (Conway 2002) so care to avoid disturbance of those owls will be taken. Radial perimeter surveys near known burrow locations will be performed in an attempt to locate new burrows on the site. 
HNF-54294

Revision 0

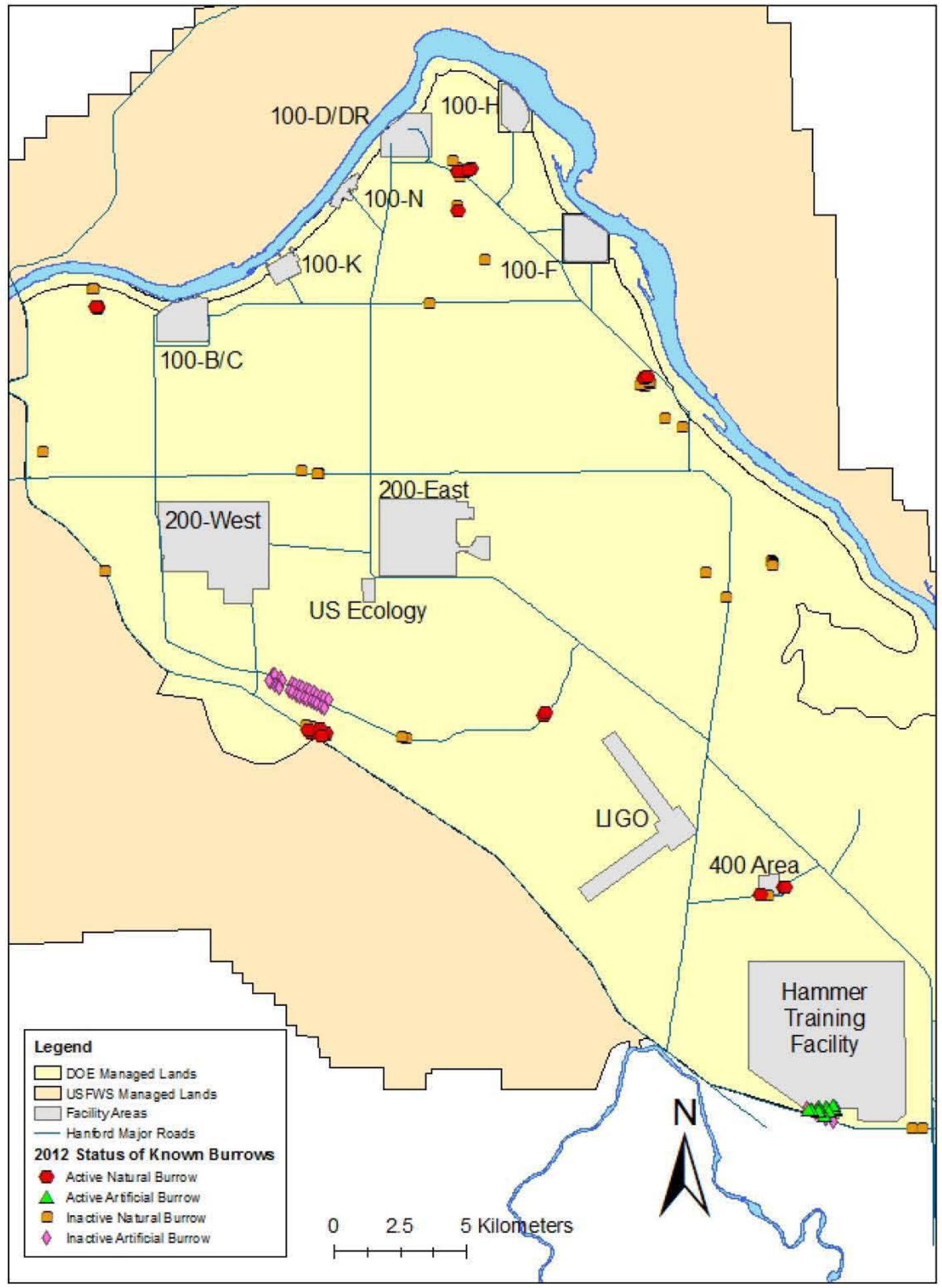

Figure 8. Current known extent of Burrowing owl burrow locations on DOE Managed Lands 
HNF-54294

Revision 0

\subsection{References}

Bradbury, J.R., Newsome, H.L. 2010. Patterns of burrow use by burrowing owls (Athene cunicularia) at the Mid-Columbia River National Wildlife Refuge Complex. Visual Aide, Washington State Chapter of The Wildlife Society meeting, February 16-19-2010

Conway, C. J., and K. L. Pardieck. 2006. Population trajectory of Burrowing Owls (Athene cunicularia) in eastern Washington. Northwest Science 80:292-297. Online at http://pubs.er.usgs.gov/publication/5224739.

Conway, C. J., V. Garcia, M. D. Smith, and L. A. Ellis. 2002. Population Ecology and Habitat Use of Burrowing Owl in Eastern Washington: 2002 Annual Report. USGS Arizona Cooperative Fish and Wildlife Research Unit, Tucson, Arizona. 50 pp. Online at http://wdfw.wa.gov/wildwatch/owlcam/bo2002ap.pdf.

Coulombe HN. 1971. "Behavior and Population Ecology of the Burrowing Owl, Speotyto cunicularia, in the Imperial Valley of California." The Condor 73:162-176. Online at http://www.jstor.org/stable/1365837.

Haug, E. A., B. A. Millsap, and M. S. Martell. 1993. Burrowing Owl (Speotyto cunicularia). In The Birds of North America, No. 61 (A. Poole, and F. Gill, eds.). The Academy of Natural Sciences, Philadelphia, PA, and The American Ornithologists' Union, Washington, D.C. Online at http://bna.birds.cornell.edu/bna/species/061.

Levy, D. J., R. S. Duncan, and C. F. Levins. 2004. Use of Dung as a Tool by burrowing Owls. Nature 431: 9. Online at http://www.nature.com/nature/iournal/v431/n7004/full/431039a.html. 
HNF-54294

Revision 0

\section{Appendix}

Hanford Site Burrows Activity Status in 2010 and 2012 
Hanford Site Burrows Activity Status in 2010 and 2012

\begin{tabular}{|c|c|c|c|c|}
\hline Site Name & Burrow Construction & Use Type & STATUS 2010 & STATUS 2012 \\
\hline $100 \mathrm{BC}-1$ & MAN-MADE & NEST & active & Active \\
\hline $100 B C-1 A$ & MAN-MADE & SATELLITE & unk & Active \\
\hline $100 B C-1 B$ & MAN-MADE & SATELLITE & unk & inactive, potential \\
\hline $100 B C-1 C$ & MAN-MADE & SATELLITE & active & active \\
\hline $100 B C-2 A$ & MAN-MADE & UNK & inactive & inactive, potential \\
\hline $100 B C-2 B$ & MAN-MADE & SATELLITE & inactive & inactive, potential \\
\hline $100 \mathrm{BC}-3$ & MAN-MADE & NEST & inactive & inactive \\
\hline $100 B C-3 A$ & MAN/COYOTE & UNK & unk & inactive, unusable \\
\hline 100D-1 & MAN-MADE & UNK & inactive & inactive, potential \\
\hline AREVA-1 & BADGER & NEST & inactive & inactive, unusable \\
\hline AREVA-2 & BADGER & NEST & inactive & inactive, unusable \\
\hline Army Loop_WCH1 & Artificial & UNK & $\mathrm{n} / \mathrm{a}$ & inactive, potential \\
\hline Army Loop_WCH10 & Artificial & UNK & $\mathrm{n} / \mathrm{a}$ & inactive, potential \\
\hline Army Loop_WCH2 & Artificial & UNK & $\mathrm{n} / \mathrm{a}$ & inactive \\
\hline Army Loop_WCH3 & Artificial & UNK & $\mathrm{n} / \mathrm{a}$ & inactive, potential \\
\hline Army Loop_WCH4 & Artificial & UNK & $\mathrm{n} / \mathrm{a}$ & inactive, potential \\
\hline Army Loop_WCH5 & Artificial & UNK & $n / a$ & inactive \\
\hline Army Loop_WCH6 & Artificial & UNK & $\mathrm{n} / \mathrm{a}$ & inactive, potential \\
\hline Army Loop_WCH7 & Artificial & UNK & $n / a$ & inactive, potential \\
\hline Army Loop_WCH8 & Artificial & UNK & $\mathrm{n} / \mathrm{a}$ & inactive, potential \\
\hline Army Loop_WCH9 & Artificial & UNK & $\mathrm{n} / \mathrm{a}$ & inactive, potential \\
\hline ARMY-1 & BADGER & NEST & inactive & inactive \\
\hline ARMY-1A & BADGER & SATELLITE & inactive & inactive, unusable \\
\hline ARMY-2 & UNKNOWN & NEST & inactive & active \\
\hline ARMY-2a & MAMMAL & UNK & $\mathrm{n} / \mathrm{a}$ & Active \\
\hline FFTF-1 & BADGER & NEST & active & active \\
\hline FFTF-1A & MAMMAL & SATELLITE & $\mathrm{n} / \mathrm{a}$ & Active \\
\hline FFTF-1B & MAMMAL & SATELLITE & $\mathrm{n} / \mathrm{a}$ & active \\
\hline FFTF-2 & MAN-MADE & NEST & inactive & inactive, potential \\
\hline FFTF-3 & MAN-MADE & NEST & inactive & inactive, potential \\
\hline FFTF-3A & BADGER & NEST & active & potentially active \\
\hline GABL-1 & MAN-MADE & NEST & inactive & Inactive, potential \\
\hline H240-1 & BADGER & NEST & active & inactive, destroyed \\
\hline $\mathrm{H} 240-1 \mathrm{~A}$ & BADGER & SATELLITE & active & inactive, destroyed \\
\hline H240-1B & BADGER & UNK & active & active \\
\hline $\mathrm{H} 240-1 \mathrm{C}$ & BADGER & SATELLITE & inactive & inactive, destroyed \\
\hline H240-1D & BADGER & UNK & inactive & inactive \\
\hline $\mathrm{H} 240-2$ & BADGER & NEST & active & inactive, potential \\
\hline $\mathrm{H} 240-3$ & BADGER & UNK & active & inactive, potential \\
\hline $\mathrm{H} 240-3 \mathrm{~A}$ & BADGER & UNK & active & inactive, potential \\
\hline
\end{tabular}




\begin{tabular}{|c|c|c|c|c|}
\hline Site Name & Burrow Construction & Use Type & STATUS 2010 & STATUS 2012 \\
\hline $\mathrm{H} 240-4$ & BADGER & NEST & active & active \\
\hline $\mathrm{H} 240-4 \mathrm{~A}$ & BADGER & NEST & active & active \\
\hline $\mathrm{H} 240-5$ & BADGER & NEST & active & inactive, potential \\
\hline $\mathrm{H} 240-5 \mathrm{~A}$ & BADGER & SATELLITE & inactive & inactive, destroyed \\
\hline $\mathrm{H} 240-6$ & BADGER & SATELLITE & inactive & inactive, destroyed \\
\hline $\mathrm{H} 240-6 \mathrm{~A}$ & BADGER & NEST & active & inactive, potential \\
\hline $\mathrm{H} 240-6 \mathrm{~B}$ & BADGER & SATELLITE & active & inactive, potential \\
\hline $\mathrm{H} 240-6 \mathrm{C}$ & BADGER & SATELLITE & active & active \\
\hline $\mathrm{H} 240-7$ & BADGER & SATELLITE & active & potentially active \\
\hline $\mathrm{H} 240-8$ & UNKNOWN & UNK & active & inactive \\
\hline $\mathrm{H} 240-9$ & MAMMAL & UNK & n/a & Active \\
\hline HAMMER_1 & Artificial & UNK & $\mathrm{n} / \mathrm{a}$ & active \\
\hline HAMMER_10 & Artificial & UNK & $\mathrm{n} / \mathrm{a}$ & inactive, maintenance \\
\hline HAMMER_11 & Artificial & UNK & $\mathrm{n} / \mathrm{a}$ & active, maintenance \\
\hline HAMMER_12 & Artificial & UNK & $\mathrm{n} / \mathrm{a}$ & active \\
\hline HAMMER_13 & Artificial & UNK & $\mathrm{n} / \mathrm{a}$ & inactive, maintenance \\
\hline HAMMER_2 & Artificial & UNK & $\mathrm{n} / \mathrm{a}$ & active, maintenance \\
\hline HAMMER_3 & Artificial & UNK & $\mathrm{n} / \mathrm{a}$ & inactive, maintenance \\
\hline HAMMER_4 & Artificial & UNK & $\mathrm{n} / \mathrm{a}$ & inactive, unusable \\
\hline HAMMER_5 & Artificial & UNK & $\mathrm{n} / \mathrm{a}$ & active, maintenance \\
\hline HAMMER_6 & Artificial & UNK & n/a & active, maintenance \\
\hline HAMMER_7 & Artificial & UNK & $\mathrm{n} / \mathrm{a}$ & inactive, unusable \\
\hline HAMMER_8 & Artificial & UNK & $\mathrm{n} / \mathrm{a}$ & inactive, maintenance \\
\hline HAMMER_9 & Artificial & UNK & $\mathrm{n} / \mathrm{a}$ & inactive, maintenance \\
\hline HAMMER_PNNL1 & Artificial & UNK & $\mathrm{n} / \mathrm{a}$ & inactive \\
\hline HAMMER_PNNL10 & Artificial & UNK & $\mathrm{n} / \mathrm{a}$ & inactive, unusable \\
\hline HAMMER_PNNL11A & Artificial & UNK & $\mathrm{n} / \mathrm{a}$ & inactive, unusable \\
\hline HAMMER_PNNL11B & Artificial & UNK & $\mathrm{n} / \mathrm{a}$ & inactive, unusable \\
\hline HAMMER_PNNL11C & Artificial & UNK & $\mathrm{n} / \mathrm{a}$ & inactive unusable \\
\hline HAMMER_PNNL12 & Artificial & UNK & $\mathrm{n} / \mathrm{a}$ & inactive, unusable \\
\hline HAMMER_PNNL2 & Artificial & UNK & $\mathrm{n} / \mathrm{a}$ & active \\
\hline HAMMER_PNNL3A & Artificial & UNK & $\mathrm{n} / \mathrm{a}$ & active \\
\hline HAMMER_PNNL3B & Artificial & UNK & $\mathrm{n} / \mathrm{a}$ & active \\
\hline HAMMER_PNNL4A & Artificial & UNK & $\mathrm{n} / \mathrm{a}$ & active \\
\hline HAMMER_PNNL4B & Artificial & UNK & $n / a$ & active \\
\hline HAMMER_PNNL5 & Artificial & UNK & $\mathrm{n} / \mathrm{a}$ & active \\
\hline HAMMER_PNNL6 & Artificial & UNK & $\mathrm{n} / \mathrm{a}$ & active, maintenance \\
\hline HAMMER_PNNL7 & Artificial & UNK & $\mathrm{n} / \mathrm{a}$ & active \\
\hline HAMMER_PNNL8A & Artificial & UNK & $\mathrm{n} / \mathrm{a}$ & inactive, unusable \\
\hline HAMMER_PNNL8B & Artificial & UNK & $\mathrm{n} / \mathrm{a}$ & inactive, maintenance \\
\hline HAMMER_PNNL8C & Artificial & UNK & $\mathrm{n} / \mathrm{a}$ & inactive, maintenance \\
\hline
\end{tabular}




\begin{tabular}{|c|c|c|c|c|}
\hline Site Name & Burrow Construction & Use Type & STATUS 2010 & STATUS 2012 \\
\hline HAMMER_PNNL9 & Artificial & UNK & $n / a$ & inactive, maintenance \\
\hline HAMMER_PNNL9B & Artificial & UNK & $n / a$ & active \\
\hline HAMMER_PNNL9C & Artificial & UNK & $\mathrm{n} / \mathrm{a}$ & active, maintenance \\
\hline HolocekHS1 & BADGER & NEST & $n / a$ & active \\
\hline HolocekHS2 & BADGER & UNK & $\mathrm{n} / \mathrm{a}$ & inactive, potential \\
\hline IDF_PNNL1 & Artificial & UNK & $n / a$ & inactive \\
\hline IDF_PNNL10 & Artificial & UNK & $n / a$ & inactive \\
\hline IDF_PNNL11 & Artificial & UNK & $n / a$ & inactive, unusable \\
\hline IDF_PNNL12 & Artificial & UNK & $n / a$ & inactive, unusable \\
\hline IDF_PNNL13 & Artificial & UNK & $n / a$ & inactive, unusable \\
\hline IDF_PNNL14 & Artificial & UNK & $\mathrm{n} / \mathrm{a}$ & inactive, unusable \\
\hline IDF_PNNL15 & Artificial & UNK & n/a & inactive \\
\hline IDF_PNNL16 & Artificial & UNK & $\mathrm{n} / \mathrm{a}$ & inactive \\
\hline IDF_PNNL17 & Artificial & UNK & n/a & inactive \\
\hline IDF_PNNL18 & Artificial & UNK & $n / a$ & inactive, unusable \\
\hline IDF_PNNL19 & Artificial & UNK & $n / a$ & inactive, unusable \\
\hline IDF_PNNL2 & Artificial & UNK & $n / a$ & inactive \\
\hline IDF_PNNL20 & Artificial & UNK & $n / a$ & inactive \\
\hline IDF_PNNL21 & Artificial & UNK & $\mathrm{n} / \mathrm{a}$ & inactive, unusable \\
\hline IDF_PNNL22 & Artificial & UNK & $n / a$ & inactive, unusable \\
\hline IDF_PNNL3 & Artificial & UNK & n/a & inactive unusable \\
\hline IDF_PNNL4 & Artificial & UNK & $n / a$ & inactive unusable \\
\hline IDF_PNNL5 & Artificial & UNK & $n / a$ & inactive unusable \\
\hline IDF_PNNL6 & Artificial & UNK & $n / a$ & inactive unusable \\
\hline IDF_PNNL7 & Artificial & UNK & $n / a$ & inactive unusable \\
\hline IDF_PNNL8 & Artificial & UNK & $n / a$ & inactive unusable \\
\hline IDF_PNNL9 & Artificial & UNK & $n / a$ & inactive unusable \\
\hline MAYJ-1 & BADGER & NEST & inactive & inactive, unusable \\
\hline OLDF-1 & BADGER & NEST & inactive & inactive, potential \\
\hline OLDF-2 & MAN-MADE & NEST & active & inactive \\
\hline OLDF-2A & MAN-MADE & SATELLITE & active & Active \\
\hline OLDF-2B & MAN-MADE & SATELLITE & $n / a$ & active \\
\hline OLDF-3 & MAN-MADE & NEST & active & Active \\
\hline OLDF-3A & MAN-MADE & NEST & $n / a$ & active \\
\hline OLDF-4 & MAN-MADE & NEST & active & Active \\
\hline ORCH-1 & MAN-MADE & NEST & $n / a$ & active \\
\hline ORCH-1A & MAN-MADE & NEST & unk & active \\
\hline $\mathrm{ORCH}-3$ & MAN-MADE & NEST & inactive & Inactive, potential \\
\hline ORCH-3A & MAN-MADE & SATELLITE & inactive & Inactive, potential \\
\hline ORCH -5 & MAN-MADE & NEST & inactive & Inactive, potential \\
\hline ORCH-5A & MAN-MADE & SATELLITE & inactive & Inactive, potential \\
\hline
\end{tabular}


HNF-54294

Revision 0

\begin{tabular}{|c|c|c|c|c|}
\hline Site Name & Burrow Construction & Use Type & STATUS 2010 & STATUS 2012 \\
\hline Pit 12 A & MAMMAL & UNK & n/a & inactive \\
\hline Pit 12 B & MAMMAL & UNK & n/a & inactive \\
\hline Pit 12 C & MAMMAL & UNK & n/a & inactive \\
\hline Pit 12 D & MAMMAL & UNK & n/a & inactive \\
\hline RT1-1 & BADGER & NEST & inactive & inactive, potential \\
\hline RT11-1 & BADGER & NEST & inactive & inactive, potential \\
\hline RT11-1A & BADGER & SATELLITE & inactive & inactive, potential \\
\hline RT11-1B & BADGER & SATELLITE & inactive & inactive, potential \\
\hline RT11-2 & BADGER & NEST & inactive & inactive, potential \\
\hline RT1A-1A & BADGER & UNK & inactive & inactive, unusable \\
\hline RT2S-1 & BADGER & NEST & inactive & inactive, unusable \\
\hline SR240-1 & BADGER & UNK & unk & inactive, potential \\
\hline TOWN-1 & MAN-MADE & NEST & inactive & colony of bees \\
\hline YakBarr1 & BADGER & UNK & n/a & inactive, potential \\
\hline
\end{tabular}

